\title{
Employees Discharged in Retaliation for Resisting Employers' Antitrust Violations: The Need for a Federal Remedy
}

Eight employees, claiming to have been discharged ${ }^{1}$ for refusing to take part in their respective employers' antitrust violations, recently filed suits in federal court. ${ }^{2}$ Each plaintiff sought relief under section 4 of the Clayton Act, which provides a private damage action for "[a]ny person who shall be injured in his business or property by reason of anything forbidden in the antitrust laws."s Five courts dismissed the suits ${ }^{4}$ or directed a verdict ${ }^{5}$ for the employer-defendants on the grounds that the plaintiffs failed to allege an antitrust injury or lacked antitrust standing. ${ }^{6}$ Two courts held

1 One of the employees resigned from his job, but alleged he was forced to do so by threats from his employer. Ostrofe v. H.S. Crocker Co., 670 F.2d 1378, 1380 (9th Cir. 1982), vacated and remanded, $103 \mathrm{~S}$. Ct. 1244 (1983). This comment treats forced resignation as equivalent to discharge.

2 Bichan v. Chemetron Corp. (In re Industrial Gas Antitrust Litigation), 681 F.2d 514 (7th Cir. 1982), cert. denied, 103 S. Ct. 1261 (1983); Ostrofe v. H.S. Crocker Co., 670 F.2d 1378 (9th Cir. 1982), vacated and remanded, 103 S. Ct. 1244 (1983); Shaw v. Russell Trucking Line, 542 F. Supp. 776 (W.D. Pa. 1982); McNulty v. Borden, Inc., 542 F. Supp. 655 (E.D. Pa. 1982); Callahan v. Scott Paper Co., 541 F. Supp. 550 (E.D. Pa. 1982) (involving two plaintiffs); Perry v. Hartz Mountain Corp., 537 F. Supp. 1387 (S.D. Ind. 1982); Booth v. Radio Shack Div., Tandy Corp., No. $81-3670$ (E.D. Pa. Jan. 28, 1982) (on file with the University of Chicago Law Review).

${ }^{3}$ Clayton Act $\$ 4,15$ U.S.C. $\S 15$ (1982). Section 4 is the vehicle whereby plaintiffs can sue for damages incurred from violations of any of the substantive sections of the antitrust laws.

4 Bichan v. Chemetron Corp. (In re Industrial Gas Antitrust Litigation), 681 F.2d 514, 517 (7th Cir. 1982), cert. denied, 103 S. Ct. 1261 (1983); Callahan v. Scott Paper Co., 541 F. Supp. 550, 559-61 (E.D. Pa. 1982); Perry v. Hartz Mountain Corp., 537 F. Supp. 1387, 1390 (S.D. Ind. 1982); Booth v. Radio Shack Div., Tandy Corp., No. 81-3670, slip op. at 2 (E.D. Pa. Jan. 28, 1982). In Broyer v. B.F. Goodrich Co., 415 F. Supp. 193 (E.D. Pa. 1976), an employee who was discharged for giving information about his employer's pricing practices to two dealers bringing antitrust suits against the employer was found not to have suffered antitrust injury, since the discharge arose from the "fact of the litigation" rather than from the underlying violations. The court noted in dicta, however, that loss of sales commissions and bonuses might be cognizable injuries arising directly from the alleged antitrust violations. Id. at 197-98.

- McNulty v. Borden, Inc., 542 F. Supp. 655 (E.D. Pa. 1982).

- A plaintiff must satisfy two threshold requirements to recover antitrust damages: he must demonstrate "antitrust injury," i.e., he must allege an injury for which the antitrust laws were meant to provide a remedy, see Brunswick Corp. v. Pueblo Bowl-O-Mat, Inc., 429 U.S. 477, 489 (1977), and must have "antitrust standing," i.e., the particular plaintiff filing suit must be the proper party to maintain a private action for treble damages, see Associ- 
similarly situated plaintiffs to have stated a cause of action. ${ }^{7}$

Since these cases were decided, many commentators have argued that employees discharged for refusing to participate in the antitrust violations of their employers have a cause of action under section $4 .^{8}$ This comment examines the legislative histories of the Sherman and Clayton Acts $^{9}$ and the antitrust doctrine created by the courts to reach the opposite conclusion. Part I briefly discusses the current case law. Part II concludes from the legislative history

ated Gen. Contractors v. California State Council of Carpenters, 103 S. Ct. 897, 907 \& n.31 (1983); Blue Shield v. McCready, 457 U.S. 465, 476-77 (1982); Illinois Brick Co. v. Illinois, 431 U.S. 720, $728 \mathrm{n} .7$ (1977). A number of lower courts treat both elements together under the heading of "standing." See, e.g., Ostrofe v. H.S. Crocker Co., 670 F.2d 1378, 1385 (9th Cir. 1982), (distinction between antitrust injury and antitrust standing unclear), vacated and remanded, 103 S. Ct. 1244 (1983); Perry v. Hartz Mountain Corp., 537 F. Supp. 1387, 1389 (S.D. Ind. 1982) ("distinction between [standing and injury] is vague at best, and, in this case at least, is of little or no importance"). The Supreme Court has recently suggested, however, that the term "standing," because of its association with the constitutional "case or controversy" requirement of article III, U.S. CoNST. art. III, § 2, may be inappropriate for characterizing those plaintiffs who may recover for alleged antitrust injuries under $\S 4$ : "Harm to the antitrust plaintiff is sufficient to satisfy the constitutional standing requirement of injury in fact, but the court must make a further determination whether the plaintiff is a proper party to bring a private antitrust action." Associated Gen. Contractors v. California State Council of Carpenters, 103 S. Ct. 897, 907 n.31 (1983).

7 Ostrofe v. H.S. Crocker Co., 670 F.2d 1378, 1380 (9th Cir. 1982), vacated and remanded, 103 S. Ct. 1244 (1983); Shaw v. Russell Trucking Line, 542 F. Supp. 776, 780-81 (W.D. Pa. 1982). Two other courts hinted they were inclined to recognize such a cause of action but said they were bound by the contrary precedent of their circuits. McNulty v. Borden, Inc., 542 F. Supp. 655, 661 (E.D. Pa. 1982); Perry v. Hartz Mountain Corp., 537 F. Supp. 1387, 1390 (S.D. Ind. 1982). In Bowen v. Wohl Shoe Co., 389 F. Supp. 572 (S.D. Tex. 1975), the court found that a former manager of a shoe store who was discharged because she was simultaneously operating another shoe store could bring a \$ 4 suit against her former employer in her capacity as a competing entrepreneur, and added that she might recover her loss of salary and other employee benefits as well.

- Note, Antitrust Standing After Associated General Contractors: The Issue of Employee Retaliatory Discharge, 63 B.U.L. REv. 983 (1983) [hereinafter cited as Note, Antitrust Standing]; Comment, Discharged Employees: Should They Ever Have Antitrust Standing Under Section 4 of the Clayton Act?, 34 Hastings L.J. 839 (1983); Note, Employee Standing Under Section 4 of the Clayton Act, 81 MrcH. L. Rev. 1846 (1983) [hereinafter cited at Note, Employee Standing]; Comment, Employee Standing in Private Antitrust Suits: A New Element in the Balance, 51 U. CIN. L. REv. 878 (1982) [hereinafter cited as Comment, Private Antitrust Suits]; 1983 B.Y.U. L. Rev. 173; Note, Ostrofe v. H.S. Crocker Co.: Antitrust Standing Under Section 4: A Departure from the Definitional Approach, 3 Pace L. REv. 739 (1983) [hereinafter cited as Note, Definitional Approach]; see also Altman, Antitrust: A New Tool for Organized Labor, 131 U. PA. L. REv. 127, 128, 169 70 (1982) (arguing in favor of standing for unions and employees). But see Note, Standing of the Terminated Employee Under Section 4 of the Clayton Act, 25 WM. \& MarY L. REv. 341, 357-72 (1983) (arguing that traditional lower court standing tests do not justify $\S 4$ suits by discharged employees).

- Section 4 of the Clayton Act is largely a recodification of $\S 7$ of the Sherman Act. See infra notes 40-41 and accompanying text. Thus the legislative histories of both acts are relevant to the interpretation of $\S 4$ of the Clayton Act. 
that Congress was primarily interested in enforcing the antitrust laws by creating an effective remedy for consumers who suffered price overcharges from monopolization of certain interstate markets, ${ }^{10}$ and not by providing a remedy to discharged employees. Part III finds that contemporary judicial doctrine limits the class of eligible section 4 plaintiffs to those whose injuries reflect the economic loss to society of a defendant's anticompetitive actions, ${ }^{11}$ and concludes that discharged employees, because their injuries result from resistance to their employers' actions and not from the anticompetitive effects of those actions, fall outside that limitation.

Despite the conclusion that federal antitrust law is unconcerned with employer-employee coercion, the final section of this comment argues that employees are nonetheless uniquely well situated to discover and expose antitrust violations, and should be protected in so doing. The comment concludes that employees could best be protected by a no-retaliation amendment to the antitrust laws rather than by an ad hoc extension of the Clayton Act's treble damage provision.

\section{Recent Employee Discharge Cases}

Six of the eight employees who brought section 4 suits $^{12}$ to recover for retaliatory discharge had held high managerial positions in their companies. ${ }^{13}$ According to their pleadings, each plaintiff

10 See Associated Gen. Contractors v. California State Council of Carpenters, 103 S. Ct. $897,904 \&$ n.20 (1983).

${ }^{11}$ See Brunswick Corp. v. Pueblo Bowl-O-Mat, Inc., 429 U.S. 477, 489 (1976).

12 In addition to bringing suit based on $\$ 4$, one former employee also sought relief through a grievance procedure. Shaw v. Russell Trucking Line, 542 F. Supp. 776, 777 \& n.2 (W.D. Pa. 1982). Several employees combined their § 4 claims with pendent state wrongfuldischarge claims but were uniformly unsuccessful. McNulty v. Borden, Inc., 542 F. Supp. 655, 656 (E.D. Pa. 1982); Callahan v. Scott Paper Co., 541 F. Supp. 550, $561-63$ (E.D. Pa. 1982); Perry v. Hartz Mountain Corp., 537 F. Supp. 1387, 1388-89 (S.D. Ind. 1982); see also Shaw, 542 F. Supp. at 779 (plaintiff permitted to amend complaint to include wrongful discharge claim).

is Bichan was the president of Chemetron Corporation's Industrial Gas Division. Bichan v. Chemetron Corp. (In re Industrial Gas Antitrust Litigation), 681 F.2d 514, 515 (7th Cir. 1982), cert. denied, 103 S. Ct. 1261 (1983). Ostrofe was the marketing director of H.S. Crocker Company, a paper label manufacturer. Ostrofe v. H.S. Crocker Co., 670 F.2d 1378, 1380 (9th Cir. 1982), vacated and remanded, 103 S. Ct. 1244 (1983). McNulty was a sales manager for Borden, Inc. McNulty v. Borden, Inc., 542 F. Supp. 655, 656 (E.D. Pa. 1982). Callahan and Brown had held sales management positions with Scott Paper Company for 24 and 13 years respectively, Callahan v. Scott Paper Co., 541 F. Supp. 550, 552 (E.D. Pa. 1982). Booth was a retail store manager. Booth v. Radio Shack Div., Tandy Corp., No. 81-3670, slip op. at 1 (E.D. Pa. Jan. 28, 1982). Shaw was a truckdriver. Shaw v. Russell Trucking Line, 542 F. Supp. 776, 777 (W.D. Pa. 1982). The eighth plaintiff's position is unreported. Perry v. Hartz Mountain Corp., 537 F. Supp. 1387 (S.D. Ind. 1982). 
became aware of what he deemed to be unlawful anticompetitive activity on the part of his employer and resisted by attempting to perform his job in a lawful, pro-competitive manner. ${ }^{14}$ In response to their resistance, the plaintiffs' employers fired them or forced them to resign, in some cases after exerting extreme pressure on them to cooperate. ${ }^{15}$ Two of the former employees claimed to have been blacklisted from their industries following their discharges. ${ }^{16}$ The plaintiffs claimed damages for lost salary, bonuses, opportunities for advancement, and diminished reputations. ${ }^{17}$ In one case, the plaintiffs also sought to enjoin their former employer's antitrust violations. ${ }^{18}$

The lower courts addressing these claims apparently agreed that the plaintiffs' loss of employment constituted an injury to

14 Bichan deviated from the established practice in his industry by competing for customers allocated to other gas producers. Bichan v. Chemetron Corp. (In re Industrial Gas Antitrust Litigation), 681 F.2d 514, 515 (7th Cir. 1982), cert. denied, 103 S. Ct. 1261 (1983). Ostrofe refused to aid his employer in a conspiracy among label manufacturers to rig bids, fix prices, and allocate markets. Ostrofe v. H.S. Crocker Co., 670 F.2d 1378, 1380 (9th Cir. 1982), vacated and remanded, $103 \mathrm{~S}$. Ct. 1244 (1983). McNulty refused to offer deals to one supermarket chain that were not offered to competitors. McNulty v. Borden, Inc., 542 F. Supp. 655, 656 (E.D. Pa. 1982). Callahan and Brown, upon learning that Scott Paper Company was offering discounts and promotional allowances to favored customers only, exposed and attempted to halt this practice. Callahan v. Scott Paper Co., 541 F. Supp. 550, 552 (E.D. $\mathrm{Pa}$. 1982). Shaw refused to violate Pennsylvania law by driving trucks loaded above a maximum weight allowance, tried to persuade other drivers to follow his example, and threatened to notify authorities of the practice of overloading. Shaw v. Russell Trucking Line, 542 F. Supp. 776, 777, 781 (W.D. Pa. 1982). It is unclear what provision of the antitrust laws Shaw considered his employer's practice to violate. Plaintiff Perry refused to induce exclusive dealings with retailers by means of pay-offs and fraudulent credits, or to tie pet-care product sales to carpet-care product sales. Perry v. Hartz Mountain Corp., 537 F. Supp. 1387, 1387-89 (S.D. Ind. 1982). Booth refused to carry out practices allegedly designed to promote price discrimination and resale price maintenance. Booth v. Radio Shack Div., Tandy Corp., No. 81-3670, slip op. at 1 (E.D. Pa. Jan 28, 1982).

${ }_{15}$ In Ostrofe v. H.S. Crocker Co., 670 F.2d 1378, 1380 (9th Cir. 1982), vacated and remanded, $103 \mathrm{~S}$. Ct. 1244 (1983), for example, Ostrofe's superiors allegedly warned him that he would sacrifice promised compensation and a greater share in the company's management and that he would be discharged and blacklisted from the industry unless he stopped interfering with the unlawful scheme.

${ }^{16}$ Bichan v. Chemetron Corp. (In re Industrial Gas Antitrust Litigation), 681 F.2d 514, 515 (7th Cir. 1982), cert. denied, 103 S. Ct. 1261 (1983); Ostrofe v. H.S. Crocker Co., 670 F.2d 1378, 1380 (9th Cir. 1982), vacated and remanded, 103 S. Ct. 1244 (1983). While the Bichan court did not discuss the alleged boycott, the Ostrofe court found the boycott aimed at Ostrofe to be itself a violation of the Sherman Act, $670 \mathrm{~F} .2 \mathrm{~d}$ at 1381.

17 See, e.g., Bichan v. Chemetron Corp. (In re Industrial Gas Antitrust Litigation), 681 F.2d 514, 515 (7th Cir. 1982) (lost salary and bonuses), cert. denied, 103 S. Ct. 1261 (1983); Callahan v. Scott Paper Co., 541 F. Supp. 550, 553 (E.D. Pa. 1982) (diminished compensation, opportunity to increase sales, potential for advancement, and reputation).

${ }_{18}$ Callahan v. Scott Paper Co., 541 F. Supp. 550, 552-53 (E.D. Pa. 1982). The court did not address the request for injunctive relief because it found the plaintiffs' claims not to be cognizable under the antitrust laws. Id. at 561 n.2. 
"business or property" within the meaning of the Clayton Act ${ }^{19}$ but disagreed both as to whether the plaintiffs had "standing" to sue under section 4 and as to the appropriate inquiry to undertake in resolving that issue. In Bichan v. Chemetron Corp., ${ }^{20}$ the Seventh Circuit applied the "target area" test, which limits the section 4 remedy to plaintiffs within the market threatened, by virtue of the antitrust violation, with a breakdown of competition. ${ }^{21}$ Because the conspiracy alleged by Bichan was targeted at the industrial gas market and not at the labor market, the Court held that Bichan's discharge was not cognizable under the antitrust laws. ${ }^{22}$ By contrast, in Ostrofe v. H.S. Crocker Co. ${ }^{23}$ the Ninth Circuit criticized the target area test, among others, ${ }^{24}$ for leading to inconsistent results ${ }^{25}$ and applied a "balancing of competing policy interests" approach to find that the importance of employee suits to effective antitrust enforcement outweighed their potential for "vexatious litigation and excessive liability."28 The court thus held that a complaint alleging a plaintiff's discharge in retaliation for opposing the anticompetitive practices of his employer stated a cause of action under section $4 .{ }^{27}$

Four district courts from the Third Circuit, which purportedly followed a "balancing of factors" approach in determining the propriety of section 4 suits, ${ }^{28}$ reached disparate results. ${ }^{28}$ One federal

10 This issue was discussed expressly by only one court. See McNulty v. Borden, Inc., 542 F. Supp. 655,660 (E.D. Pa. 1982). In other contexts, however, the courts have recognized that loss of employment can be a cognizable injury under § 4. See, e.g., Radovich v. National Football League, 352 U.S. 445, 447-48, 454 (1957) (employee claiming that he was prevented from gaining employment by an anticompetitive labor boycott held to state $\S 4$ claim); Nichols v. Spencer Int'l Press, Inc., 371 F.2d 332, 334 (7th Cir. 1967) (“[O]ne who has been damaged by loss of employment as a result of a violation of the antitrust laws is 'injured in his business or property' . . ."); Roseland v. Phister Mfg. Co., 125 F.2d 417, 419 (7th Cir. 1942) ("business or property" includes employment).

${ }^{20} 681$ F.2d 514 (7th Cir. 1982), cert. denied, 103 S. Ct. 1261 (1983).

21 Id. at 516.

23 Id. at 517.

2s 670 F.2d 1378 (9th Cir. 1982), vacated and remanded, 103 S. Ct. 1244 (1983).

24 In addition to rejecting the "target area" test of Karseal Corp. v. Richfield Oil Corp., 221 F.2d 358, 362 (9th Cir. 1955), the Ninth Circuit also rejected the "direct injury" test of Reibert v. Atlantic Richfield Co., 471 F.2d 727, 731 (10th Cir. 1973), and the "zone of interests" test of Malamud v. Sinclair Oil Corp., 521 F.2d 1142, 1151 (6th Cir. 1975). See Ostrofe, 670 F.2d at 1378, 1382 n.6 (9th Cir. 1982), vacated and remanded, 103 S. Ct. 1244 (1983).

${ }^{28} 670$ F.2d at 1382 .

26 Id. at 1383.

27 Id.

28 See Bravman v. Bassett Furniture Indus., 552 F.2d 90, 99 (3d Cir. 1977) ("§ 4 standing analysis is essentially a balancing test comprised of many constant and variable factors ...."), cert. denied, 434 U.S. 823 (1978).

20 Compare Shaw v. Russell Trucking Line, 542 F. Supp. 776, 781 (W.D. Pa. 1982), with 
judge in the Western District of Pennsylvania followed Ostrofe to hold that a discharge in retaliation for refusing to participate in an alleged antitrust conspiracy is cognizable because it "flows directly" from the unlawful conduct. ${ }^{30}$ Three judges from the Eastern District of Pennsylvania held otherwise. The first summarily held that only actual purchasers have standing to complain of price discriminations in violation of section 2(a) of the Clayton Act, ${ }^{31}$ and not employees allegedly fired in furtherance of the conspiracy to discriminate. ${ }^{32}$ The second found it "manifest" that the antitrust laws were designed only to protect plaintiffs at whom the defendant directed its anticompetitive practices, or whose injury was otherwise "a consequence of a breakdown in competitive conditions";33 the court held that discharged employees satisfied neither test. The third court denied standing on the ground that a discharge in retaliation for opposing an employer's antitrust violation does not "directly result[] from the economic effects" of the alleged violation. ${ }^{34}$ Since the decisions in these cases, the Supreme Court has, as a general matter, rejected the analyses the courts used for determining the scope of section 4 standing and injury, ${ }^{35}$ but it has not addressed the subject of employee suits in particular. ${ }^{36}$

\section{Legislative HrstoRy of Section 4}

The literal language of the Clayton Act is broad enough to encompass every harm directly or indirectly attributable to an antitrust violation. ${ }^{37}$ The Supreme Court has repeatedly emphasized,

Booth v. Radio Shack Div., Tandy Corp., No. 81-3670, slip op. at 1 (E.D. Pa. Jan. 28, 1982); Callahan v. Scott Paper Co., 541 F. Supp. 550, 552 (E.D. Pa. 1982); and McNulty v. Borden, 542 F. Supp. 655, 656 (E.D. Pa. 1982).

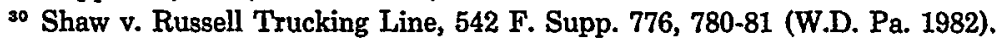

${ }^{31} 15$ U.S.C. $\S 13(a)$ (1982).

32 Booth v. Radio Shack Div., Tandy Corp., No. 81-3670, slip op. at 2 (E.D. Pa. Jan. 28, 1982).

ss Callahan v. Scott Paper Co., 541 F. Supp. 550, 560 (E.D. Pa. 1982).

s4 McNulty v. Borden, 542 F. Supp. 655, 661 (E.D. Pa. 1982).

35 In Associated Gen. Contractors v. California State Council of Carpenters, $103 \mathrm{~S}$. Ct. 897, 907-08 \& n.33 (1983), the Court explicitly rejected the tests that had been developed by the lower courts for determining $\$ 4$ standing. Instead, the Court called for an open-ended, multi-factor inquiry.

ss The Court subsequently vacated the judgment of the Ninth Circuit in Ostrofe, and remanded for reconsideration in light of Associated Gen. Contractors v. California State Council of Carpenters, 103 S. Ct. 897 (1983). The Court denied certiorari to the Seventh Circuit in Bichan, 103 S. Ct. 1261 (1983)

${ }^{37}$ Associated Gen. Contractors v. California State Council of Carpenters, 103 S. Ct. 897, 904 (1983). See supra text accompanying note 3 for statutory language. 
however, that such an open-ended reading of the statute is not what Congress intended ${ }^{38}$ and that courts should limit treble-damage awards to those injuries that reflect Congress's core concerns. ${ }^{39}$ This section examines the legislative history of the antitrust laws to determine whether employee suits properly fall within that core. Section 4 of the Clayton Act, enacted in $1914,4^{40}$ is largely a recodification of section 7 of the Sherman Act of $1890 .{ }^{11}$ The legislative history of that earlier provision demonstrates that Congress was chiefly concerned with creating an effective weapon against the giant trusts and combinations that then dominated certain interstate markets. ${ }^{42}$ By creating a private right of action, Congress hoped to supplement the limited enforcement resources of the gov-

${ }^{38}$ See, e.g., id. at 905-07 (Congress assumed common law rules would apply to and constrain antitrust suits); Blue Shield v. McCready, 457 U.S. 465, 477 (1982) ("It is reasonable to assume that Congress did not intend to allow every person tangentially affected by an antitrust violation to maintain an action to recover threefold damages . . . ."); Hawaii v. Standard Oil Co., 405 U.S. 251, 263 n.14 (1972) ("Congress did not intend the antitrust laws to provide a remedy in damages for all injuries that might conceivably be traced to an antitrust violation.").

30 Associated Gen. Contractors v. California State Council of Carpenters, 103 S. Ct. 897, 910 (1983) ("In each case [the plaintiff union's] alleged injury must be analyzed to determine whether it is of the type that the antitrust statute was intended to forestall."); Blue Shield v. McCready, 457 U.S. 465, 481 (1982) ("We turn finally to the manner in which the injury alleged reflects Congress' core concerns in prohibiting the antitrust defendants' course of conduct."); Brunswick Corp. v. Pueblo Bowl-O-Mat, Inc., 429 U.S. 477, 489 (1977) ("Plaintiffs must prove . . . injury of the type the antitrust laws were intended to prevent .....").

to Pub. L. No. 212, 38 Stat. 731 (codified at 15 U.S.C. $\$ 15$ (1982)).

41 Compare Clayton Act, $\S 4,15$ U.S.C. $\$ 5$ (1982), quoted supra text accompanying note 3, with Sherman Antitrust Act, ch. 647, \& 7, 26 Stat. 209, 210 (1890) ("Any person who shall be injured in his business or property by any other person or corporation by reason of anything forbidden or declared to be unlawful by this act. . .") repealed by Act of July 7 , 1955, ch. 283, \& 3, 69 Stat. 283.

42 Associated Gen. Contractors v. California State Council of Carpenters, 103 S. Ct. 897, $904 \& \mathrm{n} .20$ (1983).

43 See, e.g., 51 CoNG. REc. 9185 (1914) (statement of Rep. Helvering) ("It must be plain that few corporations will care to run the risk of pursuing illegal methods knowing that they will make themselves liable . . . for the payment of damages to all parties injured."), reprinted in 2 Legislative History of the Federal Antitrust Laws and RedatBd Statutes 1304 (E. Kintner ed. 1978) [hereinafter cited as LegrsLative HistoRY]; id. at 16,274 (statement of Rep. Webb) ("[Section 4] will have a more deterrent effect on the men who practice these things than a mere criminal penalty ....."), reprinted in 3 LegisLative HistorY, supra, at 2771; id. at 16,274-75 (statement of Rep. Webb) ("[T]he first 'tooth' [in the legislation] . . . is in section $4 \ldots$. If the Attorney General should be negligent, the individual himself has a wide-open door to go into court and sue.") reprinted in 3 LBGisLATIVE HisTORY, supra, at 2771-72; see also Reiter v. Sonotone Corp., 442 U.S. 330, 344 (1979) ("These private suits provide a significant supplement to the limited resources available to the $\mathrm{De}$ partment of Justice for enforcing the antitrust laws and detecting violations."); Berger \& Bernstein, An Analytical Framework for Antitrust Standing, 86 YALE L.J. 809, 849 (1977): 


\section{ernment $t^{43}$ and to ensure compensation for the victims of monopoly pricing. ${ }^{4}$}

Despite congressional interest in private enforcement, the legislative history of the Sherman Act suggests that Congress never intended a private right of action under the Sherman Act to be available to employees discharged for opposing their employers' antitrust violations. Members of Congress simply assumed that only competitors ${ }^{46}$ and consumers ${ }^{46}$ would utilize the private civil remedy. The typical suit envisioned was that of distant consumers "injured in small sums by the advanced price which they have been compelled to pay."17 Congress demonstrated its interest in vigorous private enforcement in the provisions in both the Sherman and Clayton Acts for treble damages, ${ }^{48}$ liberalized venue, ${ }^{48}$ re-

Because of budgetary considerations, the government must concentrate its resources on a few antitrust cases each year, and it must seek consent decrees rather than penalties in nearly all other cases. In contrast, the prospect of treble damages encourages private parties to bring some of the suits not brought by the government.

"Senator Sherman said of the measure that was to become $\S 7$ of the Sherman Act: "The measure of damages, whether merely compensatory, putative [sic], or vindictive, is a matter of detail depending upon the judgment of Congress ... . [This] section is to give to private parties a remedy for personal injury caused by such a combination." 21 Cong. REC. 2456 (1890), reprinted in 1 Legislative HistoRx, supra note 43, at 114-15. Twenty-four years later, in debate over enactment of the Clayton Act, Representative Webb hailed the private remedy: "This section opens the door of justice to every man, whenever he may be injured by those who violate the antitrust laws, and gives the injured party ample damages for the wrong suffered." 51 Cong. REc. 9073 (1914), reprinted in 2 Legislative History, supra note 43, at 1192.

4321 ConG. Rec. 3147 (1890) (statement of Sen. George) ("By the use of this organized force of wealth and money the small men engaged in competition . . . are crushed out, and that is the great evil at which all this legislation ought to be directed."), reprinted in 1 Legislative History, supra note 43, at 284; see also 51 Cong. Rec. 9090 (1914) (statement of Rep. Mitchell) ("IT]hose who had been crushed and driven out of business were left without a remedy . . . . "), reprinted in 2 LegisLatrve History, supra note 43, at 1229; 20 Cong. REc. 1458 (1889) (statement of Sen. George) (bill should "put an end forever to the pratice ... of large corporations ... so arranging that they dictate to the people of this country . . . what they shall receive when they sell."), reprinted in 1 LEGISLATIVE HisTORY, supra note 43 , at 77 .

18 "Who is this party injured, when ... there has been an advance in the price by the combination? . . . The consumer is the party "damnified or injured." 21 CoNG. REc. 1767 (1890), reprinted in 1 Legislative History, supra note 43, at 99 (statement of Sen. George); see also 20 Cong. Rec. 1458 (1889) (statement of Sen. George) ("I am extremely anxious that some bill shall . . . put an end forever to the practice . . . of large corporations . . . so arranging that they dictate to the people of this country what they shall pay when they purchase . . . "), reprinted in 1 LEGISLATIVE HistoRY, supra note 43, at 77.

4721 CoNG. REc. 3148 (1890) (remarks of Sen. George, arguing for aggregation of small claims), reprinted in 1 LEGISLATtve HistoRY, supra note 43, at 285; see also 21 CoNG. Rgc. 1768 (1890) (remarks of Sen. George) ("It is manifest that in nearly every instance the damage by the advanced price of each article affected by these combinations would be-though in the aggregate large, indeed-so small as not to justify the expense and trouble of a suit in a distant court."), reprinted in 1 LeGisLA'rive HistoRY, supra note 43, at 100 .

18 Clayton Act $\S 4$, 15 U.S.C. § 15 (1982); Sherman Antitrust Act, ch. 647, § 7, 26 Stat. 
covery of attorney's fees, ${ }^{50}$ and waiver of the minimum amount usually required for federal jurisdiction. ${ }^{51}$ The provision for treble damages reflects Congress's belief that, were only single or double damages available, ${ }^{52}$ the small amounts recoverable compared to the cost and difficulty of bringing antitrust suits ${ }^{53}$ would discourage private actions, thereby frustrating the deterrent purposes of the private right of action. ${ }^{54}$ Congress never expressly considered extending treble damages to discharged employees, who have easier access to proof of both the underlying violation and their own injuries than does the average antitrust plaintiff.

Extension of the private right of action to employees is made more doubtful still by the lack of evidence that Congress intended to abrogate the then pervasive contract doctrines allowing employees to be discharged at will..$^{55}$ On the contrary, Senator Sherman himself expressly disclaimed any intention of "announc[ing] a new principle of law"sB or interfering with existing state law. ${ }^{57}$ The

209, 210 (1890), repealed by Act of July 7, 1955, ch. 283, § 3, 69 Stat. 283.

10 See Associated Gen. Contractors v. California State Council of Carpenters, $103 \mathrm{~S}$. Ct. 897, 904 n.20 (1983). The venue provisions were further broadened when $\S 7$ of the Sherman Act was reenacted in 1914 as $\S 4$ of the Clayton Act, 15 U.S.C. $\$ 15$ (1982)). Under the original act, venue would lie "in the district in which the defendant resides or is found." Sherman Antitrust Act, ch. 647, § 7, 26 Stat. 209, 210 (1890), repealed by Act of July 7, 1955 , ch. 283 , 33,69 Stat. 283 . Under $\S 4$, venue in antitrust actions lies either where "the defendant resides or is found or has an agent." 15 U.S.C. $\S 15$ (a) (1982).

so Clayton Act $\S 4,15$ U.S.C. $\$ 15$ (1982); Sherman Antitrust Act, ch. 647, § 7, 26 Stat. 209, 210 (1890), repealed by Act of July 7, 1955, ch. 283, § 3, 69 Stat. 283.

os Id.

s2 An early version of the Act provided for recovery of actual damages only, S.1, 51st Cong., 1st Sess. § 2 (1889), reprinted in 1 Legislative History, supra note 43, at 89, but was amended by the Senate Committee on Finance to provide double damages, 1 LEGISLATIVE History, supra note 43 , at 93 , and then by the Committee on the Judiciary to provide treble damages, id. at 277.

ss See, e.g., 21 Cong. REc. 2456 (1890) (remarks of Sen. Sherman) ("My own opinion is that the damages should be commensurate with the difficulty of maintaining a private suit against a combination such as is described."), reprinted in 1 LegisLative History, supra note 43 , at 114.

* See Associated Gen. Contractors v, California State Council of Carpenters, $103 \mathrm{~S}$. Ct. 897, 904 n.20 (1983); Hawaii v. Standard Oil Co., 405 U.S. 251, 262 (1972). An alternative justification for the treble damages remedy offered by several recent commentators is that treble damages provide approximately the appropriate amount of deterrence since many violations go undetected. See R. Posner \& F. EAstrRrRook, ANTTrRust 544 (2d ed. 1981); Page, Antitrust Damages and Economic Efficiency: An Approach to Antitrust Injury, $47 \mathrm{U}$. ChI. L. REv. 467, 472, 476 (1980).

ss For a discussion of these doctrines, see Comment, Protecting the Private Sector AtWill Employee Who "Blows the Whistle": A Cause of Action Based Upon Determinants of Public Policy, 1977 Wis. L. Rev. 777, 782.

se See 21 Cong. Rec. 2456 (1890), reprinted in 1 Legislative History, supra note 43, at 114.

${ }^{87}$ Id.("The purpose of this bill is to enable the courts of the United States to apply the 
stated purpose of the bill was much narrower: to federalize the then-existing common law of restraints of trade and thereby to remedy the inability of state courts to reach combinations of interstate scope and effect..$^{88}$

Finally, it is significant to note that Congress deleted an early provision of the Sherman Act that would have extended the protection of the Act to any person, partnership, or corporation driven out of business for refusing "to become a party" to an unlawful antitrust combination. ${ }^{58}$ As explained by Senator Sherman, the purpose of this section was to "protect a weak person from being compelled . . . by threats or intimidation against being forced into a combination of this kind ...." Who While it is unclear whether this provision would have provided relief for the employees seeking recovery under section 4 today, ${ }^{61}$ the provision itself is telling evidence that the statute's draftsmen distinguished between persons injured for refusal to participate in antitrust conspiracies and those injured "by reason of" the violation itself. Under the present wording of the Clayton Act, only the latter group may sue under section 4.

Courts and commentators that find employee suits cognizable under section 4 have ignored these express statements of limitation and the telling omissions in the legislative history and have concentrated instead on the enactors' interests in vigorous antitrust

same remedies against combinations which injuriously affect the interests of the United States that have been applied in the several States to protect local interests."); see also 21 CoNG. REc. 3146 (1890) (remarks of Sen. Hoar) ("We have affirmed the old doctrine of the common law in regard to all interstate and international commercial transactions, and have clothed the United States courts with authority to enforce that doctrine . . . ."), reprinted in 1 LEgislative HistoRy, supra note 43, at 282.

ss 21 Cong. REc. 2456 (1890) (remarks of Sen. Sherman) ("The power of the State Courts has been repeatedly exercised to set aside such combinations as I shall hereafter show, but these courts are limited in their jurisdiction to the State, and . . . are admitted to be unable to deal with the great evil that now threatens us."), reprinted in 1 LEGisLATIVE History, supra note 43, at 114 .

s9 The Senate bill read in part:

[I]f one of the purposes of any such arrangement, contract, agreement, trust, or combination shall be to compel any person, partnership, or corporation to become a party thereto, or to cease from doing any lawful business . . the person, partnership, or corporation injured thereby may sue . . . .

S. 3445, 50th Cong., 2d Sess. § 3 (1889), reprinted in 1 Legislative History, supra note 43, at 74 .

so 21 Cong. REc. 1168 (1889), reprinted in 1 Legislative HistoRy, supra note 43, at 69.

-1 The wording of the proposed provision allowed recovery only to persons who would themselves have been a "party" to the agreement and so probably would not have covered all agents of the offending corporations. Cf. infra notes 73-75 and accompanying text (discussing scope of employee liability under the criminal provisions of the Sherman and Clayton Acts). 
enforcement. ${ }^{62}$ Allowing treble damage suits by employees discharged for refusal to cooperate with an anticompetitive scheme, it is argued, would help expose antitrust violations otherwise likely to remain undetected, ${ }^{63}$ and would deter antitrust violations by presenting employers with the unattractive choice between effecting unlawful policies over the resistance of employees or risking lawsuits and exposure of the violations by discharging insubordinate employees. This reliance on Congress's overall purpose without regard for the specific legislative history of the Sherman Act is misguided. The treble damage remedy was enacted to provide consumers who been charged excessive prices sufficient incentive to sue, ${ }^{64}$ not to remove the contractual disincentives facing employees in their efforts to resist the anticompetitive schemes of their employers. However compelling the argument that such employees deserve protection, that policy judgment is nowhere found in the legislative history of either the Sherman Act or the Clayton Act.

The Ninth Circuit in Ostrofe v. H.S. Crocker Co ${ }^{65}$ argued to the contrary, inferring congressional concern with employee behavior from the fact that the Sherman and Clayton Acts both impose criminal liability on corporate agents. ${ }^{68}$ Liability of low-level and managerial employees, however, is not clear from the statutory language of either provision; both provisions seem to apply only to parties to the unlawful agreement and not to those merely charged with its execution. ${ }^{67}$ It is significant that no cases in which non-

${ }^{62}$ See, e.g., Ostrofe v. H.S. Crocker Co., 670 F.2d 1378, 1383-84 (9th Cir. 1982), vacated and remanded, 103 S. Ct. 1244 (1983); Note, Employee Standing, supra note 8, at 1847-48.

os Cf. Berger \& Bernstein, supra note 43 , at 847 \& $n .172$ ("[T] trust violations is much lower than that of other crimes because an antitrust violation is usually a concealed crime and there is rarely an identifiable victim who is aware of the violation." ") (quoting Statement before the Tenth New England Antitrust Conference, Nov. 20, 1976, reprinted in 790 Antitrust \& Trade Reg. ReP. (BNA) D-1 (1976)); Wheeler, Antitrust Treble-Damage Actions: Do They Work?, 61 CAL. L. Rev. 1319, 1329 \& n.47 (1973) (effects of violations are difficult to distinguish from those of legitimate competition since victims often do not know antitrust law and since violations such as price-fixing that would most likely give rise to successful suits are the most difficult to detect).

or See supra notes 45-54 and accompanying text.

ss 670 F.2d 1378 (9th Cir. 1982), vacated and remanded, 103 S. Ct. 1244 (1983).

68 Id. at 1387-88; see also Note, Antitrust Standing, supra note 8, at 994. ("Congress [by imposing criminal liability on corporate agents] indicated that it was fundamentally concerned with employee participation in anticompetitive schemes.").

${ }^{87}$ Section 1 of the Sherman Act provides that "[e]very person who shall . . . engage in any combination or conspiracy hereby declared to be illegal shall be deemed guilty of a felony . . . " 15 U.S.C. $\S 1$ (1982). The Sherman Act thus limits criminal liability to actual parties to the combination of conspiracy. Section 14 of the Clayton Act reads:

Whenever a corporation shall violate any of the penal provisions of the antitrust laws, 
officers or non-directors were indicted or convicted have been reported. ${ }^{68}$ Even if one were to assume that all employees were subject to criminal liability, the fact that Congress chose to deter employee participation in antitrust violations through threats of prosecution does not demonstrate a decision to protect their resistance as well. The potential unsoundness of imposing a statutory duty without providing protection for employees who would carry it out is not an excuse for stretching the statute beyond its intended reach. ${ }^{69}$

\section{Judicial Doctrines Construing Section 4}

Under current law, antitrust plaintiffs must meet three independent requirements for recovery under section $4 .{ }^{70}$ First, under the doctrine of "antitrust injury" announced in Brunswick Corp. $v$. Pueblo Bowl-O-Mat, Inc., ${ }^{71}$ the injury for which damages are sought must be related to the anticompetitive effects of the challenged conduct. Second, even where the Brunswick test is satisfied, the injury must not be too "remote" or "indirect" to justify the awarding of treble damages. ${ }^{72}$ Third, section 4 suits must be dis-

such violation shall be deemed to be also that of the individual directors, officers, or agents of such corporation who shall have authorized, ordered, or done any of the acts constituting in whole or in part such violation ....

15 U.S.C. $\S 24$ (1982). Employee liability under the Clayton Act seems to depend only on the employee's having "done" any of the acts constituting such a violation; employees who do not participate in the agreement itself, however, may lack the necessary mens rea for criminal liability, see United States v. Wise, 370 U.S. 405, 416 (1962) (knowing participation element of criminal liability under the antitrust laws); 21 CoNG. REc. 140 (1889) (statement of Sen. Turpie) ("The essence of the trust is the guilty intention of the conspirators."); 1 Legislative History, supra note 43 , at 92.

${ }^{68}$ The early cases discuss only the liability of directors and officers. See e.g., United States v. Wise, 370 U.S. 405, 407 n.1 (1962) ("[T]he Solicitor General cites 40 cases in which corporate officers were indicated under the Sherman Act between 1890 and 1914."), id. at 416 (" $[\mathrm{A}]$ corporate officer is subject to prosecution under $\S 1$ of the Sherman Act whenever he knowingly participates in effecting the illegal contract, combination, or conspiracy-be he one who authorizes, orders or helps perpetrate the crime . . . ."); Hartford-Empire Co. v. United States, 323 U.S. 386, 434 (1945) (suggesting that the statutory term "agents" refers to officers and directors).

${ }_{60}$ Otherwise, the same argument would support a cause of action for employees discharged for resisting an employer's conspiracy to violate the tax laws, or any other law imposing criminal liability on corporate officers, for example, the Elkins Act, 49 U.S.C. $\$ 11904$ (Supp. IV 1978). Where Congress has decided to confer such a cause of action, it has done so explicitly. See infra notes $115-17$ and accompanying text.

${ }^{70}$ The analysis in this part follows that of Blue Shield v. McCready, 457 U.S. 465, 47384 (1982).

${ }^{71} 429$ U.S. 477 (1977).

${ }^{72}$ Blue Shield v. McCready, 457 U.S. 465, 476 (1982); Illinois Brick Co. v. Illinois, 431 U.S. 720,728 n.7 (1977). 
missed if the judicial complexities of allocating speculative or duplicative recoveries threaten to undermine effective enforcement of the antitrust laws. ${ }^{73}$ While the loss of a job for refusing to participate in an employer's anticompetitive scheme arguably implicates neither the concern with remoteness nor the concern with duplicative recovery, ${ }^{74}$ this section will demonstrate that employee suits are nonetheless barred for failure to meet the Brunswick requirement. ${ }^{35}$

\section{A. Brunswick Antitrust Injury}

In Brunswick, a unanimous Court held that only those injuries that "reflect the anticompetitive effect" of an alleged antitrust violation are compensable under section $4 .^{76}$ Brunswick itself concerned the allegedly unlawful acquisition of defaulting bowling centers by a bowling equipment manufacturer. The Court held that competing bowling center owners could not recover damages for profits they would have realized had their defaulting competitors gone out of business. The Court reasoned that even if the acquisition had been unlawful under section 7 of the Clayton Act, ${ }^{77}$

7s Associated Gen. Contractors v. California State Council of Carpenters, 103 S. Ct. 897, 911-912 (1983); Blue Shield v. McCready, 457 U.S. 465, 475 n.11 (1982); Illinois Brick Co. v. Illinois, 431 U.S. 720, 745 (1977); Hawaii v. Standard Oil Co., 405 U.S. 251, 264 (1972).

${ }^{73}$ See, e.g., Note, Employee Standing, supra note 8, at 1862-65.

73 Most courts and commentators have regarded the finding of a Brunswick "antitrust injury" to be a necessary prerequisite for section 4 recovery. See, e.g., Bichan v. Chemetron Corp. (In re Industrial Gas Antitrust Litigation), 681 F.2d 514, 516 (7th Cir. 1982), cert. denied, 103 S. Ct. 1261 (1983); Chrysler Corp. v. Fedders Corp., 643 F.2d 1229, 1235 (6th Cir. 1981); Page, supra note 54, at 497; Note, Antitrust Standing, supra note 8, at 1004; Note, Employee Standing, supra note 8, at 1848. The Supreme Court itself, however, has been less clear on the subject. See, e.g., Associated Gen. Contractors v. California State Council of Carpenters, 103 S. Ct. 897, 908-910 (1983) (Brunswick one of many factors discussed by the Court in determining propriety of $\$ 4$ suit); Blue Shield v. McCready, 457 U.S. 465, 483 n.19 (1982) (Brunswick "one factor to be considered in determining redressability of a particular . . . injury under $\S 4 . ")$. That plaintiff-employees may suffer injuries which are not too remote and which present little danger of judicial complexity does not, however, justify a departure from the antitrust-injury requirement of Brunswick. Brunswick stated in absolute terms that "[p]laintiffs must prove antitrust injury," 429 U.S. at 489 (emphasis omitted), and grounded this dictate in the "by reason of" language of $\S 4$. See id. at 488 ("[I]t is quite clear that if respondents were injured, it was not "by reason of anything forbidden in the antitrust laws." "). Moreover, a brief examination of Supreme Court decisions reveals that the antitrust injury requirement is implicit in questions of remoteness and duplicative recovery, since only a prior showing of anticompetitive effects will trigger the latter inquiries. Cf. Blue Shield v. McCready, 457 U.S. 465, 478 (1982) (second half of test for remoteness restates Brunswick antitrust injury requirement); id. at 474-75 (risk of duplicative recovery engendered by tracing anticompetitive effects along full chain of distribution).

76 429 U.S. at 489.

${ }^{37} 15$ U.S.C. $\$ 18$ (1982). Section 7 prohibits acquisitions that may substantially lessen 
the monopoly power of the new entrant was not the cause of the plaintiffs' lost profits; the effect of the acquisition on the plaintiffs would have been the same had no antitrust violation occurred. ${ }^{78}$ Because the plaintiffs suffered from increased competition-an "injury" for which compensation would be antithetical to the antitrust laws' purposes-relief was denied. The court stated:

We ... hold that for plaintiffs to recover treble damages on account of section 7 violations, they must prove more than injury causally linked to an illegal presence in the market. Plaintiffs must prove antitrust injury, which is to say injury of the type the antitrust laws were intended to prevent and that flows from that which makes defendants' acts unlawful. ${ }^{79}$

The antitrust laws are concerned with acts that concentrate market power and lead to the market inefficiencies of restricted output and raised prices. ${ }^{80}$ Pueblo Bowl-O-Mat fell outside section 7 because it was injured by a side effect of an unlawful merger (the continued operation of failing competitors) and not by that aspect of the merger (Brunswick's share of market power) that threatened to lessen competition. ${ }^{81}$ Recalling that the antitrust laws "were enacted for "the protection of competition, not competitors," "82 the Brunswick Court reasoned that to allow Pueblo Bowl-O-Mat recovery would mean that "all dislocations caused by the merger' are actionable, regardless of whether those dislocations have anything to do with the reason the merger was condemned."83

Brunswick articulates a concern that damages recovered in section 4 suits reflect the economic loss to the market that is the chief concern of the antitrust laws. ${ }^{84}$ Allowing recovery by discharged employees would not advance that concern. An employee's dilemma between participating in an antitrust violation and risking the loss of his job may be an immediate consequence of an employer embarking on an anticompetitive course of action. Nonetheless, the employee's injury bears no relation to the anticompeti-

competition or tend to create monopolies.

${ }^{78} 429$ U.S. at $487-88$.

${ }^{70}$ Id. at 489.

80 See 1 P. Areeda \& D. Turner, Antrtrust Law fit 103-05 (1978).

${ }^{81}$ Cf. Page, supra note 54, at 471 ("[A]ntitrust injury . . . narrow[s] the standard for recoverable damages from all those suffered by the plaintiff as a result of an antitrust violation to those that actually flow from the aspect of the violation that causes market inefficiency.").

${ }_{82} 429$ U.S. at 488 (quoting Brown Shoe Co. v. United States, 370 U.S. 294, 320 (1962)).

ss Id. at 487.

st See Page, supra note 54, at 476-487. 
tive effects of the employer's activities. Were the employer violating the securities, tax, or any other laws, the employee's dilemma would be the same. By the same token, the extent of the effect on competition of the employer's scheme is irrelevant to the measure of the employee's injury. To allow employees to recover treble damages for their discharges would divorce antitrust damages from those harms to the market with which Congress was primarily concerned.

\section{B. The Reach of Brunswick}

Commentators advocating section 4 recovery for discharged employees have sought to ignore the implications of the antitrust injury requirement by arguing that Brunswick stands only for the proposition that lower courts should not "divorce[] antitrust recovery from the purposes of the antitrust laws"85 by awarding damages for injuries suffered as a result of increased competition. ${ }^{86}$ While the Supreme Court's subsequent decision in Blue Shield $v$. $M c C r e a d y^{87}$ contains some general language to this effect, ${ }^{88}$ a closer analysis of that case, and of the Supreme Court's recent decision in Associated General Contracts v. California State Council of Carpenters, ${ }^{89}$ demonstrates that Brunswick cannot be so limited.

McCready concerned an allegedly unlawful conspiracy in the psychotherapy market brought about through a group health insurance plan that reimbursed its subscribers for treatment by psy-

8s Brunswick, 429 U.S. at 487.

so See Note, Employee Standing, supra note 8, at 1849-50 \& n.16; Comment, Private Antitrust Suits, supra note 8, at 892-93 \& n.116; see Note, Definitional Approach, supra note 8, at 765-66. The court in Ostrofe v. H.S. Crocker Co., 670 F.2d 1378 (9th Cir. 1982), vacated and remanded, 103 S. Ct. 1244 (1983), tried to limit Brunswick further by questioning its applicability to sections 1 and 2 of the Sherman Act. 670 F.2d at 1386. This suggestion was then picked up by one commentator who concludes that Brunswick applies only to mergers, presumably on the grounds that proof that a merger is unlawful requires a demonstration only of a likelihood of restraint of trade and that the further proof of actual injury required under $\S 4$ obviates the antitrust injury requirement. Comment, Private Antitrust Suits, supra note 8, at 883 n.41. In light of the Supreme Court's subsequent application of Brunswick to three non-merger cases, this argument is no longer tenable. See Associated Gen. Contractors v. California State Council of Carpenters, 103 S. Ct. 897, 908-10 (1983) (Brunswick applied to coercive refusal to deal); Blue Shield v. McCready, 457 U.S. 465, 48184 (1982) (Brunswick applied to conspiracy to suppress competition between psychologists and psychiatrists); J. Truett Payne Co. v. Chrysler Motors Corp., 451 U.S. 557, 561-63 (1981) (Brunswick applied to price discrimination).

87457 U.S. 465 (1982).

s8 Id. at 482 ("Brunswick . . . embrac[es] the general principle that treble-damages recoveries should be linked to the procompetition policy of the antitrust laws.").

ss 103 S. Ct. 897 (1983). 
chiatrists but not by psychologists. McCready, a subscriber under the plan, sought treble damages based on the cost of Blue Shield's refusal to reimburse her for expenses incurred in seeing a psychologist. $^{90}$ Relying on Brunswick, the defendants argued that McCready did not pay artificially inflated fees for psychiatric treatment, but chose to continue seeing a psychologist; therefore, they argued, her injury did not reflect the anticompetitive effect of the alleged boycott. ${ }^{91}$

A bare majority of the Supreme Court disagreed. As it had in Brunswick, the Court framed its inquiry in terms of whether McCready's alleged injury 'reflects Congress' core concerns in prohibiting the ... defendants' course of conduct." Cready's injury to be "inextricably intertwined with the injury the conspirators sought to inflict on the psychologists and the psychotherapy market," the Court held that McCready's injury fell "squarely within the area of Congressional concern." The Court neither rescinded nor purported to narrow the Brunswick requirement of antitrust injury. Rather, the Court found the Brunswick test satisfied when participants in the relevant market refuse to pay monopoly prices but then suffer direct market coercion as a consequence of that decision.

In Associated General Contractors, the plaintiff union alleged that the defendant, a multi-employer association with whom it had entered into a collective bargaining agreement, coerced association members and other third parties into hiring non-union subcontractors and encouraged non-members to refuse to bargain collectively with the plaintiffs.94 The union claimed that this coercion adversely affected the trade of unionized firms and restrained their contracting activities..$^{95}$ In an 8-1 decision, ${ }^{96}$ the Court held that the complaint failed, as a matter of law, to allege an injury within the meaning of section $4 .^{97}$

In reaching this conclusion, the Court contrasted the plaintiff union, "neither a consumer nor a competitor in the market in which trade was restrained,"98 with McCready, who was both a

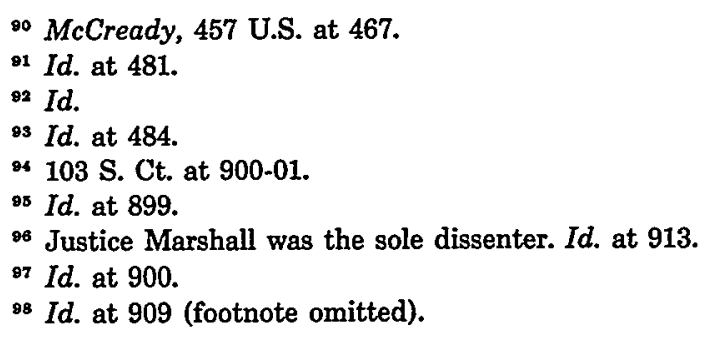


participant in the relevant economic market (psychotherapeutic services) and a direct victim of the defendants' unlawful coercion. ${ }^{99}$ The Court reasoned that the union's injury, unlike that of the subcontractors affected by the association's coercion, or of McCready, primarily concerned its "labor-market interests,"100 not its economic freedom to participate in the contracting market. The Court therefore held that the Brunswick requirement had not been met. ${ }^{101}$

Taken together, McCready and Associated General Contractors suggest that Brunswick cannot be read so strictly as to limit antitrust recovery to plaintiffs who are forced to pay monopoly prices or who suffer from restrictions of output, nor so broadly as to allow recovery for injuries that bear no necessary relation to the market effects of an alleged violation. As was true of the union in Associated General Contractors, it is not clear whether employees who refuse to participate in an antitrust violation "would be served or disserved by enhanced competition in the market." 102 Therefore, their "alleged injury must be analyzed to determine whether it is of the type that the antitrust statute was intended to forestall."10s The employees' complaint is not that their economic freedom in the market affected by the employer's anticompetitive activity has been limited; their injury is primarily to their labor-market interest in retaining their jobs on acceptable terms. ${ }^{104}$

The resemblance of the choice confronting these employees to the "Hobson's Choice"10s presented to McCready, though superficially attractive, is ultimately misleading. Though both are given the choice between participating in an anticompetitive scheme or suffering injury, McCready's participation would have been as an

"Id. at 910 n.44.

${ }^{100} \mathrm{Id}$. at 910.

101 Id.

102 Id. at 909.

103 Id. at 910.

104 One commentator has suggested that "because at-will employees are not covered by a separate body of federal labor law, the employees' antitrust concerns predominate." Note, Employee Standing, supra note 8, at 1862. This argument assumes its conclusion. While the Court in Associated General Contractors observed that the union's injuries were arguably within the ambit of federal labor law, that observation was merely part of a larger inquiry into whether the interests that the union alleged to have been injured wexe interests whose protection would promote "uninhibited competition among employers." Only an affirmative response to this inquiry, the Court noted, would constitute the union "part of the class the Sherman Act was designed to protect." See 103 S. Ct. at 909-10. An employee's interest in protection from unjust discharge, like a union's interest in improving working conditions, will often be unrelated, if not opposed, to the interest of promoting competition.

${ }^{105} \mathrm{McCready}$, 457 U.S. at 483. 
antitrust victim, the employee's as an antitrust violator. McCready's choice - that of paying monopoly prices by seeing a psychiatrist or incurring out-of-pocket losses by foregoing reimbursement-went to the "heart"106 of the anticompetitive scheme she alleged. By forfeiting reimbursement, McCready simply deflected the antitrust injury that "would have been borne" by competitors in the market onto herself, and thereby bore immediately an injury she and other consumers would inevitably have suffered "in the form of suppressed competition in the psychotherapy market."107 The employee who forfeits his job to protest what he perceives to be an anticompetitive scheme, by contrast, faces a moral dilemma divorced from the anticompetitive aspects of the allegedly unlawful conduct and unrelated to his own economic freedom to participate in the market threatened by the employer's anticompetitive designs. However necessary the employee's cooperation may be to the success of the antitrust scheme, his injury, suffered for refusal to cooperate, is not "inextricably intertwined"108 with its market effects.

\section{Proposal for Congressional Action}

Courts and commentators have strained the meaning of section 4 of the Clayton Act to find within it protection for employees who resist their employers' anticompetitive schemes. The temptation to do so is considerable, for these employees are uniquely well situated to promote effective antitrust enforcement, ${ }^{109}$ and yet are at risk of losing their jobs should they so act. State law offers some protection for terminated employees in the form of wrongful discharge suits, ${ }^{110}$ but wrongful discharge claims are not recognized in

$108 I d$.

107 Id.

108 Id. at 484.

109 See Note, Employee Standing, supra note 8, at 1864-65; see also supra note 63 (antitrust violations particularly difficult for public to detect).

110 The general rule of American employment, unlike that in any other industrialized nation, is that a non-union, non-government employee is terminable at will. Note, Protecting At Will Employees Against Wrongful Discharge: The Duty to Terminate Only in Good Faith, 93 Harv. L. Rev. 1816, 1816, 1844 (1980); Comment, supra note 55, at 780, 782. Termination can be for "good cause, for no cause, or even for cause morally wrong." Payne v. Western \& A.R.R., 81 Tenn. 507, 519-20 (1884). To mitigate counterproductive or inequitable results of this rule, courts in a minority of states-California, Connecticut, Idaho, Illinois, Indiana, Kansas, Maryland, Massachusetts, Michigan, Missouri, Montana, New Hampshire, New Jersey, New York, Oregon, Pennsylvania, Texas, Virginia (federal bankruptcy court applying state law), Washington, and West Virginia-have created "public policy exceptions" to the employment-at-will doctrine. Labor Special Products UNIT, The Bureau of National Affairs, Inc., The Employment-AT-Will Issue 8 (1982) [hereinafter cited as 
the majority of states. ${ }^{111}$ Moreover, state courts should not be in the business of making federal law enforcement a matter of state public policy. Nonetheless, section 4 is an unsatisfactory answer to this problem. Section 4 was intended to deter anticompetitive behavior, not to protect employees; it is not a thoughtful congressional regulation of employer-employee relations, nor a delicate balance between the need for protection of whistle-blowing employees and the need for cooperation of employees in corporate operations. A full-scale trial to prove that a violation of the antitrust laws has occurred should not be required for the protection of employees who act in a reasonable, good-faith belief that a violation has occurred. Similarly, the strict civil liability that section 4 imposes on violators for any breakdowns in competition ${ }^{112}$ seems inappropriate in the context of employee-employer relations, wherein an employer should perhaps prevail upon a showing of a good faith belief that its policies were lawful and that its employee, by his recalcitrance, had become an obstacle to its operations.

Finally, the section 4 remedy is not well tailored to the unique problems of insider suits. The statute makes no distinction among the protections it would accord to rank-and-file employees, who might rarely have knowledge of antitrust law standards or violative schemes but have little freedom to choose how to perform their jobs, to managers, who might have somewhat greater knowledge and freedom but no voice in corporate decisions, and to officers or directors, who have decision making power and a duty to abide by the law. Treble damages may be inappropriate compensation for those employees with little to lose and much to gain by bringing suits in which they ordinarily have easier access to proof than does the average antitrust plaintiff. ${ }^{113}$

BNA RRPoRT]; see Smith v. Atlas Off-Shore Boat Serv., 653 F.2d 1057 (5th Cir. 1981) (federal court looks to nonmaritime law and finds relief for employee fired in retaliation for filing workmen's compensation claim); Tameny v. Atlantic Richfield Co., 27 Cal. 3d 167, 164 Cal. Rptr. 839, 610 P.2d 1330 (1980) (relief for employee dischrarged for refusing to participate in an illegal price-fixing scheme); Petermann v. International Bhd. of Teamsters, 174 Cal. App. 2d 184, 188-89, 344 P.2d 25, 27 (1959) (relief for employee terminated in retaliation for refusal to commit perjury in government investigation of employer's activities); Kelsay v. Motorola, Inc., 74 Ill. 2d 172, 384 N.E.2d 353 (1978) (relief for employee discharged in retaliation for filing workmen's compensation claim); Scott v. Union Tank Car, 402 N.E.2d 992 (Ind. Ct. App. 1980) (same); Murphy v. City of Topeka-Shawnee County Dept. of Labor Servs., 6 Kan. App. 2d 488, 630 P.2d 186 (1981) (same).

11 See, e.g., Phillips v. Goodyear Tire \& Rubber Co., 651 F.2d 1051, 1055-56 (5th Cir. 1981) (no right of action under Georgia or Texas law for employee terminated in retaliation for testifying at antitrust trial); BNA REPORT, supra note 110, at 7-8.

112 United States v. United States Gypsum Co., 438 U.S. 422, 436 n.13 (1978).

11 Although antitrust violations are often difficult for the public to detect, see supra 
That antitrust law is not suited, and state law not sufficiently comprehensive, to protect employee refusals to participate in the antitrust violations of their employers leaves a significant social problem unattended. A better tool for safeguarding employees' ability to resist antitrust violations would be a thoughtfully tailored no-retaliation amendment to the antitrust laws, rather than an ad hoc extension of the reach of a statute whose structure and content are not designed to deal with problems of employment relations. ${ }^{114}$ In several other areas where Congress has deemed employee enforcement of the law desirable, federal law provides employees with protection against retaliation. Generally, such protection is granted in statutes that regulate employer-employee relations, such as the National Labor Relations Act, ${ }^{116}$ the Fair Labor Standards Act, ${ }^{116}$ and Title VII of the Civil Rights Act of 1964. ${ }^{117}$ In 1978, however, Congress passed a statute protecting government employees who blow the whistle on unlawful govern-

note 63 and accompanying text, insiders generally have earlier and greater access to information about violations, see supra note 109 and accompanying text.

116 [D]irect legislation is a more effective and more appropriate method of promoting [social] objectives [than the antitrust laws as written]. Within any plausible bounds of statutory interpretation, antitrust law can at best make only a marginal contribution to them. Moreover, the weighing and resolution of conflicting interests and objectives would involve the courts in essentially political decisions for which there are no workable legal standards, and would often place them in a regulatory or supervisory role for which they are ill-equipped.

1 P. AREEDA \& D. TurNer, supra note 80, in 105, at 13.

115 It shall be an unfair labor practice for an employer -

(1) to interfere with, restrain, or coerce employees in the exercise of the rights guaranteed in section 157 of this title [rights of employees to organization, collective bargaining, etc.];

(3) by discrimination in régard to hire or tenure of employment or any term or condition of employment to encourage or discourage membership in any labor organization ....;

(4) to discharge or otherwise discriminate against an employee because he has filed charges or given testimony under this subchapter[.]

29 U.S.C. § 158(a)(1), (3), (4) (1982).

${ }^{116}$ [I]t shall be unlawful for any person -

(3) to discharge or in any other manner discriminate against any employee because such employee has filed any complaint or instituted or caused to be instituted any proceeding under or related to this chapter ....

29 U.S.C. § 215(a)(3) (1982).

117 It shall be an unlawful employment practice for an employer to discriminate against any of his employees . . . because he has opposed any practice made an unlawful employment practice by this subchapter, or because he has made a charge, testified, assisted, or participated in any manner in an investigation, proceeding, or hearing under this subchapter.

42 U.S.C. $\$ 2000 \mathrm{e}-3(\mathrm{a})(1976)$. 
mental activities unrelated to employment regulation-the Civil Service Reform Act of 1978. ${ }^{118}$

To protect employees who disclose or resist their employers' antitrust violations, Congress would need to adjust the burdens of proof, the class of protected employees, and the level of damages and other remedies available in such an action to achieve an appropriate level of antitrust enforcement and to strike the proper balance between the interests of employees and employers-an undertaking beyond the scope of this comment. Nonetheless, the Civil Service Reform Act might serve as a model for a no-retaliation statute designed to encourage employees to act as private attorneys general in enforcing the antitrust laws.

\section{Conclusion}

Employees who are discharged for resisting their employers' antitrust violations suffer injury that often goes unremedied under present law. The treble-damage remedy of the Clayton Act is available only to those plaintiffs whose injuries result from the anticompetitive effects of monopolistic practices, and employee discharge is a labor-market injury only peripherally related to the effects of an employer's anticompetitive venture in the market over which he seeks to exert control.

The majority of states does not allow suits by employees discharged for whistle blowing or resisting criminal activity. As a result, employees have little incentive to resist or disclose antitrust violations and great reason to fear doing so. Yet employees are

118 Pub. L. No. 95-454, § 101(a), 92 Stat. 1114, 1116 (codified at 5 U.S.C. $\S 2302(\mathrm{~b})(8)(\mathrm{A})(\mathrm{i})(1982))$. The Senate report reads in part:

Often, the whistle blower's reward for dedication to the highest moral principles is harassment and abuse. Whistle blowers frequently encounter severe damage to their careers and substantial economic loss. . . . Whenever misdeeds take place in a Federal agency, there are employees who know that it has occurred and who are outraged by it. What is needed is a means to assure them that they will not suffer if they help uncover and correct administrative abuses.

S. Rep. No. 969, 95th Cong. 2d Sess. 8 (1978).

Michigan has enacted a similar statute, the Whistleblowers' Protection Act, Mrch. Comp. LAws ANN. $\$ \$ 15.361-.369$ (West 1981). Section 15.362 reads in pertinent part: "An employer shall not discharge, threaten, or otherwise discriminate against an employee ... because the employee ... . reports or is about to report, verbally or in writing, a violation or a suspected violation of a law or regulation or rule ... unless the employee knows that the report is false . . . " The remedies provision of the statute, $\S 15.364$, reads in pertinent part: " $A$ court, in rendering a judgment in an action brought pursuant to this Act, shall order, as the court considers appropriate, reinstatement of the employee, the payment of back wages, full reinstatement of fringe benefits and seniority rights, actual damages, or any combination of these remedies." 
uniquely powerful antitrust law enforcers, both because of their inside knowlege and because of the wrench that their resistance can throw into employers' illegal plans. The Clayton Act is poorly designed to protect such employees. Therefore it is Congress's task to enact a no-retaliation law that strikes an appropriate balance among the economic benefits of employee exposure of antitrust violations, the employers' needs for cooperative employees, and the employees' needs for protection from employers' retaliatory practices.

Laurie N. Feldman 